\title{
CCNE1 Gene Amplification
}

National Cancer Institute

\section{Source}

National Cancer Institute. CCNE1 Gene Amplification. NCI Thesaurus. Code C36682.

A molecular genetic abnormality indicating the presence of multiple copies of the CCNE1 gene. 